\section{Origins of human T-lymphotropic viruses}

SIR-Joseph Rosenior finds it hard to understand why we have postulated that human $\mathrm{T}$ lymphotropic virus (HTLV-I) originated in Africa ${ }^{1}$. We were surprised by his belief that Japan did not have contact with Europeans until the eighteenth century. While it is true that "Japan was virtually cut off economically and politically from the rest of the world", it is striking that the initial contacts with Portuguese explorers during the sixteenth century occurred precisely in areas of Southern Japan where HTLV-I is endemic. The first Portuguese contact arrived in $1543^{2}$, In 1549, Saint Francisco Xavier, a Jesuit missionary, arrived in Kagoshima. He later gained Lord Omura Sumita's sanction to use the Port of Nagasaki. This port prospered and became a large commercial centre. The Portuguese established themselves throughout the southern portion of Japan and their influence and contact with the Japanese became frequent. It is known that the Portuguese took Africans with them to Japan. The Africans' presence can be seen in Portuguese pictorial records known as Nanban-Byobu, where the artist depicted Portuguese, Japanese and Africans together ${ }^{3.4}$.

Further, it is believed that the Portuguese came with African monkeys. The Japanese word for monkey amakawa is thought by Jiujirô Cogâ to be derived from the Portuguese word macaco also meaning monkey (ref. 5 and p.92, ref. 1).

Recently, Hino et al. supported this conclusion by demonstrating that the proportion of HTLV-I disease was correlated with the incidence of Japanese Catholics ${ }^{6}$, again consistent with this hypothesis. A virus similar to HTLV-I was found in Japanese macaques, stimulating an alternative idea that HTLV-I entered Japan from a monkey. However, viruses like HTLV-I were also found in many African monkeys ${ }^{7}$ and Yoshida, Seiki and colleagues recently found that the African monkey virus (STLV-I) is almost identical to the HTLV-I in man (African and Japanese) ${ }^{8}$.

Rosenior is also surprised that we think that HTLV-III, the virus which causes AIDS, also originated in Africa. He states "that HTLV-III occurs . . . in some flocks of European sheep." It is ironic that he refers to our own work (with M. Gonda), although he has misinterpreted the results. Visna virus of sheep is very distantly related to HTLV-III. Both viruses probably have a very ancient ancestral origin in common. HTLV-III is much more closely related to the simian virus STLV-III, the virus isolated by Essex and colleagues from African green monkeys. All current data from HTLV-I and HTLV-III support an African origin for these two human retroviruses. Just as important, no alternative reasonable hypothesis has been presented.

Finally, the origin of the only other human retrovirus, HTLV-II, is unknown, but its relatedness (about $50 \%$ of the genome) to HTLV-I suggests that HTLVII and HTLV-I have common ancestry.

Robert C. Gallo ANN H. SLISKI

Laboratory of Tumor Cell Biology,

National Cancer Institute,

National Institutes of Health,

Bethesda, Maryland 20205, USA

Carlos M.C. de Noronha

FERNANDO DE NORONHA

Department of Veterinary Microbiology, Cornell University,

Ithaca, New York 14853, USA

1. Rosenior, J. Nature 318, 100 (1985)

2. Matsuda, K. The Relations between Portugal and Japan, (Junta de Investigacóes do Ultramer e Centro de Estudos Históricos Ultramarinos, Lisboa, 1965).

3. Boxer, C.R. The History of Portuguese in Japan 10-11 (Kegan Paul, London, 1929); As viagens de Japão e os seus capitães-móres (1550-1640), 17-18 (Escola Tippgräfica do Oratöorio de S. J Bosco Salesianos-Macau 1949).

4. Nagayama, T. Collection of Historic Materials Connected with the Roman Catholic Religion in Japan (Kirishitan Shirio-Sho) Nagasaki, 13 (1924).

5. Norton, L. Os Portugueses no Japão (1543-1640) (Notas e Documentos) 35-36 (Agência Geral do Ultramar, Divisăo de Publicaçōes e Bibliotëca, Lisboa 1952).

. Hino, S. Kinoshita, K. \& Kitamura, Y. Lancet ii, 572-573 (1984)

Miyoshi, I et al. Lancet ii, 958-959 (1982)

. Watanabe, T. et al. Virology 144, 59-65 (1985).

\section{Bovine leukaemia virus and multiple sclerosis}

SIR-Koprowski et al. provide evidence that the serum and spinal fluid of multiple sclerosis patients contain antibody which cross-reacts with human $T$-cell viruses and that cells from the spinal fluid contain RNA which hybridizes with human $T$ lymphotropic virus (HTLV) type I under low-stringency conditions ${ }^{1}$. But is it possible that the 'footprints' which they have found are actually those of bovine leukaemia virus (BLV)?

There are strong geographic correlations between production and consumption of dairy products and multiple sclerosis $^{2}$. Moreover, milk from cows shedding BLV has caused leukaemia in chimpanzees ${ }^{3}$ and there is epidemiological evidence linking cattle herds infected by this virus with human leukaemia ${ }^{4}$. Therefore, it seems likely that BLV can be transmitted in dairy products and cause disease in humans.

It also seems likely that the viral traces found in multiple sclerosis patients could have been left by BLV. Antisera to BLV proteins cross-react with those of human T-cell viruses. Amino acid microsequencing and statistical analysis reveal 9 common amino acid residues out of 24 possible comparisons when the $\mathrm{NH}_{2}$-terminal sequences from the core proteins of HTLV p24 are aligned. The probability that this sequence homology is due to chance is only $0.4 \times 10^{-10}$ (ref.5). Nucleic acid hybridization experiments thus far reveal a sequence homology of $11 \%$ between the RNA of BLV and $\mathrm{HTLV}^{6}$.

Diets low in saturated fats (with sharp reduction in the use of dairy products) are said to help patients with multiple sclerosis $^{7}$ and the Guillain-Barré syndrome ${ }^{8}$. It is an interesting coincidence that one of the control subjects studied by Koprowski et al. was a patient with Guillain-Barré syndrome who also had antibody to HTLV.

In the aggregate, these facts should prompt some consideration of BLV infection in patients with multiple sclerosis and, perhaps, certain other neurological syndromes of unknown cause.

Allan S. Cunningham Mary Imogene Bassett Hospital, Cooperstown, New York 13326, USA

Koprowski, H. et al. Nature 318, 154-160 (1985).

Agranoff, B. \& Goldberg, D. Lancet ii, 1061-1066 (1974).

Lancet ii, 30-31 (1974)

4. Donham, K.J. et al. Am. J. Epidem. 112, $80-92$ (1980)

Oroszlan, S. et.al. Proc, natn. Acad. Sci. U.S.A. 79, 1291-1294 (1982).

Reitz, M.S. Jr et al. Proc. natn. Acad. Sci. U.S.A. 78 1887-1891 (1981).

Field, E.J. J. R. Soc. Med. 72, 487-488 (1979)

8. Bower, B.D. \& Newsholme, E. A. Lancet i, 583-585 (1978).

\section{Endogenous retrovirus} in multiple sclerosis?

SIR-In their recent article ${ }^{1}$ Koprowski et al. described the presence, in sera from some patients suffering from multiple sclerosis, of antibodies reactive with antigens of the human T-lymphotropic viruses HTLV-I, -II and-III. Although the authors did not distinguish between healthy blood donors possessing no anti-viral antibodies or those possessing antibodies only occasionally in lower titres (there was no definition of cut-off in the enzyme-linked immunosorbent assay), they cautiously suggested that infection by an exogenous, so far unknown retrovirus strain might be involved in the development of multiple sclerosis. The induction of antibodies that cross-react with such immunologically divergent strains as HTLV-I and -III and the inhibition by both HTLV-I and -III of antibody binding to HTLV-I p24 suggest that the putative multiple sclerosis strain must be very different from the two strains investigated. Testing of sera from multiple sclerosis patients against a variety of available animal retrovirus antigens may help to predict more precisely the antigenic composition of a putative multiple sclerosis retrovirus.

However, there is an alternative explanation for the data reported, namely the possible activation of a human endogenous retrovirus in cells of multiple sclerosis patients either directly by infection with viruses (such as measles, varicella, influenza) often associated with 